\title{
Twist is substrate for caspase cleavage and proteasome-mediated degradation
}

\author{
S Demontis ${ }^{1}, C$ Rigo', S Piccinin', M Mizzau², M Sonego', \\ M Fabris ${ }^{1}$, C Brancolini ${ }^{2}$ and R Maestro*,1 \\ 1 Unit of Molecular Mechanisms of Neoplastic Progression, Department of \\ Experimental Oncology, CRO IRCCS National Cancer Institute, Aviano, PN, \\ Italy \\ 2 Department of Biochemical Sciences and Technologies, University of Udine, \\ Udine, Italy \\ * Corresponding author: R Maestro, Unit of Molecular Mechanisms of Neoplastic \\ Progression, Department of Experimental Oncology, CRO IRCCS National \\ Cancer Institute, 33081 Aviano, PN, Italy. Tel: + 39 0434659664; \\ Fax: + 39 0434659659; E-mail: maestro@ cro.it
}

Received 03.2.05; revised 06.7.05; accepted 13.7.05; published online 12.8.05 Edited by $\mathrm{H}$ Ichijo

\begin{abstract}
Twist is a member of the basic helix-loop-helix family of transcription factors. An aberrant Twist expression has been found in diverse types of cancer, including sarcomas, carcinomas and lymphomas, supporting a role for Twist in tumor progression. Twist is known to be essential for mesodermal development. However, since a prolonged Twist expression results in a block of muscle, cartilage and bone differentiation, Twist has to be excluded from somites during late embryogenesis for terminal differentiation to occur. This implies that Twist expression must be target of a tight control. Here we provide evidence that Twist undergoes posttranscriptional regulation. Twist is substrate for cleavage by caspases during apoptosis and its cleavage results in ubiquitin-mediated proteasome degradation. Our findings suggest that Twist post-transcriptional regulation may play an important role in tissue determination and raise the possibility that alterations in the protein turnover may account for Twist overexpression observed in tumors.

Cell Death and Differentiation (2006) 13, 335-345.

doi:10.1038/sj.cdd.4401744; published online 12 August 2005
\end{abstract}

Keywords: Twist; transcription factor; apoptosis; caspase; ubiquitination

Abbreviations: bHLH, basic-helix-loop-helix; PARP, poly(ADPribose) polymerase; DMEM, Dulbecco's modified Eagle's medium; Z-VAD-FMK, Z-Val-Ala-Asp $\left(\mathrm{OCH}_{3}\right)$-FMK; Z-DEVD-FMK, ZAsp $\left(\mathrm{OCH}_{3}\right)$-Glu $\left(\mathrm{OCH}_{3}\right)$-Val-Asp $\left(\mathrm{OCH}_{3}\right)$-FMK; Ac-DEVD-CHO, Ac-Asp-Glu-Val-Asp-CHO; LLnL, $\quad N$-acetyl-Leu-Leu-Norleu-Al; MEF, mouse embryo fibroblasts; Ni-NTA, nickel-nitrilotriacetic acid

\section{Introduction}

Twist is a nuclear protein that belongs to the class $B$ of the basic helix-loop-helix (bHLH) family of transcription factors.
Twist, also known as Twist 1, was originally identified in Drosophila as an essential zygotic developmental gene involved in the establishment of dorsoventral polarity and mesoderm development. ${ }^{1}$ In mammals, Twist is mostly expressed in cranial neural crest derivatives and in mesenchymal structures ${ }^{2-5}$ and is implicated in the control of differentiation of several mesodermal cell lineages including bone, cartilage, dermis and muscle..$^{2,6-10}$ In this context, it has been shown that Twist is involved also in adult muscle regeneration. ${ }^{11}$ Mutations of the Twist gene are responsible for the Saethre-Chotzen syndrome, an autosomal dominant craniosynostosis characterized by the premature fusion of cranial sutures, skull deformations, limb abnormalities and facial dysmorphisms. ${ }^{12-16}$ These abnormalities are featured also by mice heterozygous for Twist null mutations, while the homozygous null condition is associated with early embryonic lethality due to failure in the closure of cephalic neural tube. ${ }^{17}$

Besides its role in the control of cell determination and tissue regeneration, recent evidence suggests an involvement of Twist also in cancer development. In fact, we have recently reported that Twist antagonizes p53-dependent apoptosis and growth arrest and it is overexpressed in human rhabdomyosarcomas. ${ }^{18}$ Overexpression of Twist has been subsequently reported in other types of cancer, including invasive lobular breast carcinomas ${ }^{19}$ and T-cell lymphomas. ${ }^{20}$ A role for Twist in the control of programmed cell death has been further sustained by the finding that Twist overexpression is associated with acquired drug resistance in human cancer cells. ${ }^{21}$ Moreover, it has been shown that Twist participates in IGF-1 receptor-mediated protection and modulation of TNF- $\alpha$-dependent apoptosis. ${ }^{22,23}$ Finally, calvarial osteoblasts of Saethre-Chotzen patients show increased programmed cell death compared to normal individuals, ${ }^{24}$ and Twist null mice, just prior to dying, exhibit a strong wave of apoptosis in the sites of normal expression of Twist, ${ }^{17}$ indicating that the ability of Twist to promote cell survival plays an important role in embryo development. ${ }^{25}$

The crucial role of Twist in modulating diverse processes, including developmental apoptosis, raises the question of how Twist expression is itself regulated and whether defects in Twist regulatory machinery may be responsible for the aberrant accumulation observed in human cancers.

Little is known about the mechanisms that govern Twist expression in vertebrates. In developing mice, Twist mRNA expression is limited to a restricted window of 4 days, between days 8.5 and 11.5. In particular, Twist expression can be uniformly detected in early somites but it is rapidly shut off in the differentiating myotome, as myogenic regulatory factors are upregulated. ${ }^{26} \mathrm{~A}$ sharp and strictly timed induction of Twist mRNA is observed also in adult regenerating muscle, where, again, it precedes the peak of myogenic factors. ${ }^{11}$ Taken together, these data support the existence of fine mechanisms of transcriptional control of Twist expression in both the embryo and the adult. Indeed, Twist induction has been connected to a number of pathways, including FGF- and 
BMP-regulated signaling ${ }^{26}$ and recent data point a key role for the NF- $\kappa$ B pathway in Twist control. ${ }^{22}$ However, a comparative analysis in early mouse embryos revealed discrepancies between Twist mRNA and Twist protein expression profiles. ${ }^{5}$ In fact, while Twist mRNA is detectable in the mesoderm of gastrulating embryo and in mesodermal derivatives of organogenesis-stage embryo (presomitic mesoderm, somites, cranial mesenchyme, limb buds and sutural tissues of the skull), the Twist protein is absent in these structures. Discrepancies between Twist protein and corresponding mRNA have been observed also in a relevant fraction of human tumors (R Maestro and $\mathrm{C}$ Doglioni, unpublished). On the whole, these results suggest that, in addition to a tight transcriptional control, Twist expression may be regulated also at a post-transcriptional level.

The clarification of Twist regulation could help in understanding its role in development and differentiation, but also provide important insights into the mechanisms of Twist activation in human cancer.

Here we describe that the Twist protein undergoes posttranscriptional regulation. In particular, we demonstrate that Twist is target of caspase cleavage during apoptosis and that Twist processing by caspases results in ubiquitination and proteasome-mediated degradation, providing evidence for the existence of new mechanisms for Twist regulation.

\section{Results}

\section{Twist is degraded in vivo during apoptosis}

Mouse embryo fibroblasts transformed by E1A and HaRasV12 oncogenes (E1A/Ras MEF) are highly susceptible to p53-induced apoptosis. ${ }^{27}$ The ectopic expression of Twist efficiently reduces the penetrance of the apoptotic phenotype in these cells, although intense or prolonged apoptotic stimuli can overcome the Twist protective effect. ${ }^{18}$ To determine whether this partial protective phenotype was due to changes in Twist expression during programmed cell death, E1A/Ras MEF infected with a retroviral vector driving the expression of a Myc-tagged mouse Twist cDNA were induced to apoptose by either growth factor deprivation ( 24 and $48 \mathrm{~h}$ ) or treatment with DNA damage-inducing agents (adriamycin, $0.5 \mu \mathrm{g} / \mathrm{ml}$ for 3 and $8 \mathrm{~h}$ ). Both stimuli are well-known triggers of p53mediated apoptosis in this experimental system. ${ }^{27}$ As shown in Figure 1a, induction of apoptosis results in a dramatic reduction of Twist protein expression. In control, untreated cells, Twist is expressed at high levels, decreases after a $3 \mathrm{~h}$ induction of apoptosis (adriamycin) and is barely detectable after $8 \mathrm{~h}$. In contrast, Twist mRNA levels, both ectopic and endogenous, remained unaltered under the same experimental conditions (Figure 1b). Same results were obtained in Balb/C 3T3 fibroblasts and U2OS human osteosarcoma cells

a E1A/Ras MEF

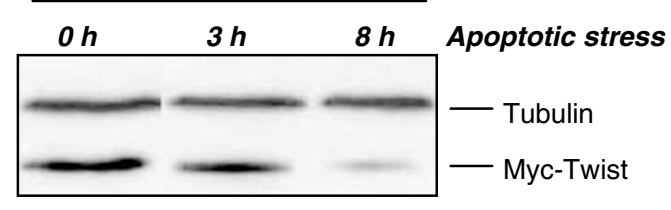

b

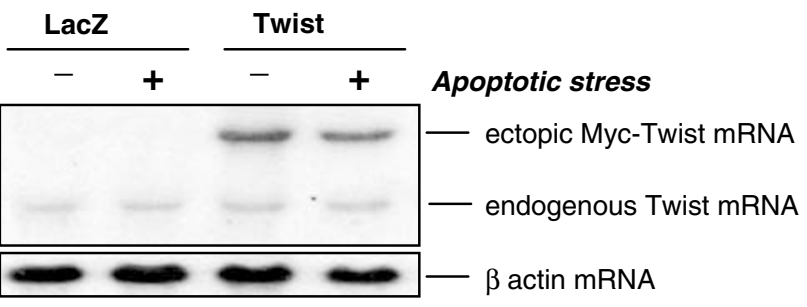

C E1A/Ras BJ E1A IMR90

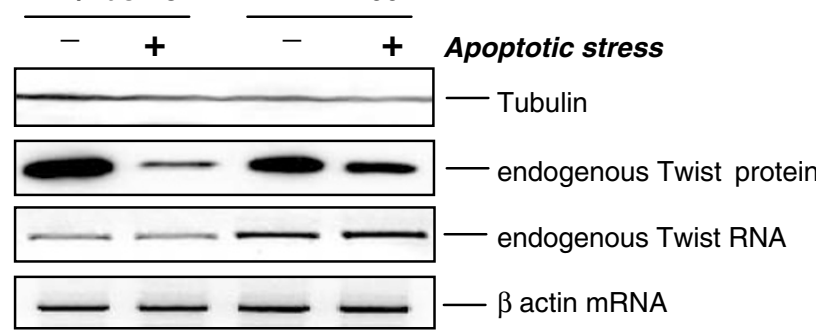

Figure 1 The Twist protein undergoes degradation during apoptosis. (a) E1A/Ras MEF infected with a retroviral vector driving the expression of Myc-Twist were induced to apoptose by adriamycin treatment $(0.5 \mu \mathrm{g} / \mathrm{ml}$ for 3 and $8 \mathrm{~h})$. Cell lysates were resolved on 10\% SDS-PAGE and analyzed for Twist expression by Western blot using an anti-Myc antibody. Expression of $\alpha$-tubulin was used as a loading control. (b) Northern blot analysis confirmed that downregulation of Twist occurred selectively at the protein level. E1A/Ras MEF infected with either a retroviral vector encoding for an irrelevant control gene (LacZ) or Myc-Twist, before $(-)$ and after $(+)$ apoptotic stress (adriamycin, $0.5 \mu \mathrm{g} / \mathrm{ml}$ for $8 \mathrm{~h}$ ), are shown. The blot was first incubated with a Twist-specific probe and then reprobed for $\beta$-actin to verify equal loading. The mouse Twist probe recognized both the ectopic and the endogenous Twist transcripts. (c) Downregulation of the Twist protein in the course of apoptosis was confirmed also on the endogenous protein. E1A/Ras BJ and E1A IMR90 human fibroblasts were subjected to apoptotic stress (cisplatin, $100 \mu \mathrm{M}$ for $24 \mathrm{~h}$ ) and analyzed for protein levels by Western blot with an anti-human Twist polyclonal serum (upper panels) and for Twist mRNA levels by RT-PCR (lower panels). Western blot and RT-PCR analyses were normalized for the expression of $\alpha$-tubulin and $\beta$-actin, respectively 
engineered to express Twist (data not shown). This apoptosis-associated protein downregulation seemed a peculiar feature of Twist, since protein levels of other cDNAs cloned in the same retroviral vector were unaffected under analogous experimental conditions (not shown).

To confirm these observations on the endogenous Twist protein, we raised a polyclonal serum specific for human Twist and tested it against in vitro-transformed human fibroblasts. $\mathrm{E} 1 \mathrm{~A} /$ Ras-transformed $\mathrm{BJ}$ (E1A/Ras BJ) and E1A-transformed IMR-90 (E1A IMR90) human fibroblasts were induced to apoptose by different apoptotic stimuli. In both human fibroblast strains, induction of apoptosis eventually resulted in Twist protein downregulation, in the absence of evident changes in Twist mRNA expression levels (Figure 1c). Again, the expression of other endogenous proteins such as $\alpha$-actin, $\alpha$-tubulin or fra1 remained unaltered in the same experimental assay.

On the whole, these data indicated that the Twist protein undergoes degradation in the course of apoptosis and supported the existence of mechanisms of post-transcriptional regulation for Twist.

\section{Twist undergoes caspase-mediated cleavage in vitro}

The observation of a downregulation of the Twist protein in the course of apoptosis prompted us to find a possible link between effectors of cell death and Twist breakdown. An in silico analysis revealed that Twist contains a putative caspase $3 / 7$ consensus site (DELD) between amino acids (aa) 170 and 173 (aa 166-169 in the human homolog), which is conserved throughout evolution (Figure 2). Caspases are cysteine proteases, which play a critical role in the apoptotic response. ${ }^{28-30}$ In particular, caspases 3 and 7 are responsible for triggering cell fragmentation through the cleavage of selected death substrates containing the common consensus sequence $D E x D$, where $x$ is any amino acid. ${ }^{31-33}$ To ascertain whether Twist putative caspase $3 / 7$ consensus site was actually a substrate for caspase proteolysis during apoptosis, we performed an in vitro cleavage assay by incubating in vitrotranslated Myc-Twist with cell lysates obtained from E1A/Ras MEF induced to apoptose by treatment with adriamycin $(0.5 \mu \mathrm{g} / \mathrm{ml}$ for $16 \mathrm{~h})$. The reaction was carried out for 2 and $6 \mathrm{~h}$ at $37^{\circ} \mathrm{C}$, and the mixture was then subjected to SDSPAGE. As shown in Figure $2 a$, incubation of in vitro-translated Myc-Twist $(43 \mathrm{kDa})$ with an apoptotic cell lysate resulted in Twist cleavage, as revealed by the appearance of a shorter fragment, undetectable in the mixture containing the nonapoptotic control lysate. The size of the new fragment $(40 \mathrm{kDa})$ was compatible with the calculated size of a Myctagged Twist protein truncated around aa 173. The smaller cleavage peptide (aa 173-206) was undetectable under the experimental conditions used because of its very limited size (about $3 \mathrm{kDa}$ ). Same results were obtained when using a FLAG-tagged Twist construct (Figure 2b).

To further provide evidence of the role of caspases in Twist proteolysis, in vitro proteolytic assays were performed in the presence of the caspase 3 inhibitor Z-DEVD-FMK (Z$\operatorname{Asp}\left(\mathrm{OCH}_{3}\right)$-Glu $\left(\mathrm{OCH}_{3}\right)$-Val-Asp $\left(\mathrm{OCH}_{3}\right)$-FMK; $\left.1 \mu \mathrm{M}\right)$. Z-DEVD- a Mouse wt Twist ${ }^{158}$ RYIDFLYQVLQSDELDSKMASC 180

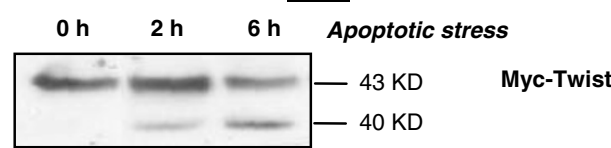

b

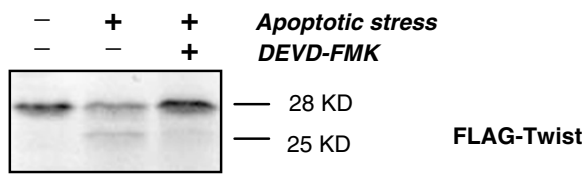

Mouse Twist D173A ${ }^{158}$ RYIDFLYQVLQSDELASKMASC ${ }^{180}$

C

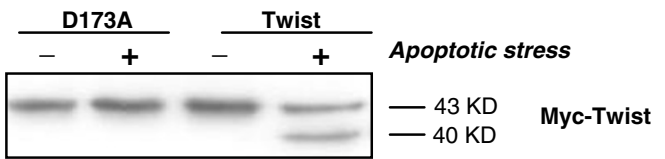

Figure 2 In vitro caspase cleavage of Twist. (a) Mouse Twist shows a putative caspase $3 / 7$ cleavage site (aa 170-173). In vitro-translated Myc-Twist (43 kDa), incubated for the indicated durations with E1A/Ras MEF apoptotic cell lysates (adriamycin, $0.5 \mu \mathrm{g} / \mathrm{ml}$ for $16 \mathrm{~h}$ ), undergoes cleavage ( $40 \mathrm{kDa}$, cleaved MycTwist). (b) Cleavage was observed also when in vitro-translated FLAG-tagged Twist protein $(28 \mathrm{kDa})$ was incubated with the same apoptotic cell lysates (25 kDa, cleaved FLAG-Twist). Caspase 3 inhibitor Z-DEVD-FMK $(1 \mu \mathrm{M})$ prevented FLAG-Twist cleavage. (c) In vitro-translated Myc-D173A Twist mutant, in which the critical aspartic acid at position 173 was substituted by an alanine, was resistant to apoptotic cell lysate-induced cleavage ( $6 \mathrm{~h}$ incubation), indicating a critical role for caspases in Twist processing

FMK inhibitor abolished the cleavage of both Myc- (not shown) and FLAG-Twist after incubation with apoptotic cell lysates (Figure $2 b$ ), thus confirming the role of caspase cleavage in Twist processing.

Caspase-induced proteolysis requires an aspartate in position P1 (corresponding to D173 of mouse Twist ${ }^{170}$ DELD ${ }^{173}$ sequence). ${ }^{31}$ To verify that the putative caspase $3 / 7$ recognition site was actually target of cleavage, the aspartic residue 173 was replaced with an alanine $\left({ }^{170} \mathrm{DELA}^{173}\right)$. As shown in Figure $2 \mathrm{c}$, the D173A mutant was clearly refractory to the cleavage by $E 1 A / R a s ~ M E F$ apoptotic lysates, even after $6 \mathrm{~h}$ of incubation.

These data confirmed that Twist is susceptible to caspasemediated cleavage at the DELD motif and that the presence of an aspartate in position 173 is key for this processing.

It has been recently shown that active caspase 3 , but not caspase 7 , translocates from the cytoplasm to the nucleus during apoptosis, providing evidence on how caspase 3 may have access to its nuclear targets. ${ }^{34}$ On this ground, being Twist a nuclear protein, an in vitro proteolytic assay with recombinant active caspase 3 was performed to ascertain the role of this effector caspase in Twist cleavage. As shown in Figure $3 a$, incubation of in vitro-translated Twist with active caspase 3 resulted in Twist processing. Twist cleavage was prevented by caspase 3-specific inhibitor DEVD-CHO. In vitro-translated caspase 2 was used as a positive control for caspase 3 activity. No processing was observed when in vitrotranslated Twist was incubated with active caspase 2 (data not shown).

To further provide insights into the role of caspase 3 in Twist proteolysis, we took advantage of MCF-7 cells, which do not express caspase $3 .^{35}$ Twist cleavage was impaired after 


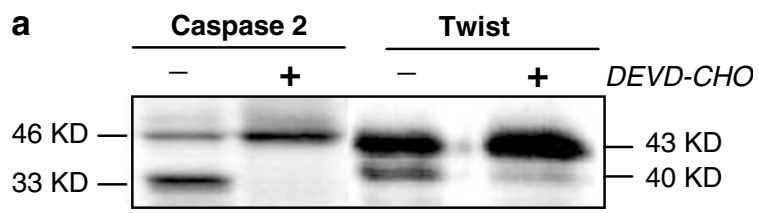

b

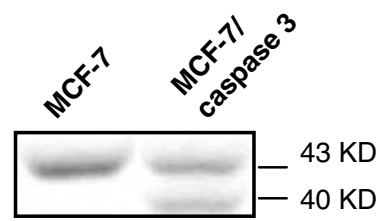

Figure 3 Role of caspase 3 in Twist cleavage. (a) In vitro-translated Twist is cleaved by recombinant caspase $3 .{ }^{35} \mathrm{~S}$-labeled in vitro-translated Myc-Twist was incubated with $0.1 \mathrm{ng}$ of recombinant caspase 3 , in the presence $(+)$ or absence $(-)$ of caspase 3 inhibitor Ac-DEVD-CHO $(2 \mu \mathrm{M})$, as indicated. Ac-DEVD-CHO inhibited caspase 3-mediated cleavage of Twist. Reactions were carried out at $37^{\circ} \mathrm{C}$ for $30 \mathrm{~min}$ and resolved on a $15 \%$ SDS-PAGE. In vitro-translated caspase 2 , a known substrate of caspase 3 , was used as a positive control of recombinant caspase 3 activity. (b) ${ }^{35}$ S-labeled in vitro-translated Myc-Twist was incubated with apoptotic cell lysates (adriamycin, $2 \mu \mathrm{g} / \mathrm{ml}$ for $24 \mathrm{~h}$ ) from naive MCF-7 cells or MCF-7 cells engineered to express caspase 3 (MCF-7/caspase 3). No cleavage of in vitro-translated Twist was detectable after $6 \mathrm{~h}$ incubation with apoptotic lysates from naive, caspase 3-deficient MCF-7 cells. Cleavage became evident only after incubation with apoptotic lysates from MCF-7/caspase 3 cells, in which the expression of caspase 3 was restored by transient transfection

incubation with apoptotic lysates from naive MCF-7 cells, whereas it was readily detectable after incubation with apoptotic lysates from MCF-7 cells that were engineered to ectopically express caspase 3 (MCF-7/caspase 3) (Figure 3b). Taken together, these data support a role for caspase 3 in Twist processing during apoptosis.

\section{Twist is processed by caspases during apoptosis}

To assess the role of caspase-mediated processing in Twist protein turnover, E1A-transformed IMR-90 cells were subjected to apoptotic stress (cisplatin, $100 \mu \mathrm{M}$ for $24 \mathrm{~h}$ ) in the presence/absence of caspase inhibitor Z-VAD-FMK (Z-ValAla-Asp $\left(\mathrm{OCH}_{3}\right)$-FMK) or Z-DEVD-FMK (100 $\mu \mathrm{M}$ for $\left.25 \mathrm{~h}\right)$. As shown in Figure $4 \mathrm{a}$, interference with caspase activity prevented, at least in part, endogenous Twist downregulation. To get better insights into the role of caspase-mediated proteolysis of Twist during apoptosis, we took advantage of E1A-transformed IMR-90 cells engineered to express a dominant-negative mutant of caspase 9 (DN Casp9 E1A IMR90). In these cells, the expression of an inactive form of caspase 9 causes the block of the caspase cascade at the level of caspase 9/APAF interaction. As a result, activation of effector caspase $3 / 7$, normally operated by caspase 9 , is hampered. $^{36}$ As shown in Figure $4 \mathrm{~b}$, interference with caspase 9 activity significantly prevented apoptosis-induced degradation of endogenous Twist, indicating that Twist downregulation in this context requires an intact caspase cascade.

To further confirm the role of caspase-mediated processing in Twist downregulation, we tested whether the Twist protein actually underwent caspase-mediated cleavage in vivo. For this purpose, we took advantage of tagged Twist constructs where the presence of the Myc epitope repeated six times (6xMyc tag) allowed the detection of Twist processing at a very high sensitivity. E1A/Ras MEF cells engineered to express either wild-type Twist or the D173A Twist mutant were induced to apoptose under different apoptotic conditions and cell lysates were analyzed by Western blot with anti-Myc antibody. We found that wild-type Twist cleavage was detectable within a narrow window of observation (adriamycin, $0.25 \mu \mathrm{g} / \mathrm{ml}$ for $11 \mathrm{~h}$ ), after which the Twist protein was rapidly degraded (Figure 4c). In contrast, no processing occurred for the D173A Twist mutant in any apoptotic condition tested, despite a strong caspase cascade activation, as revealed by poly(ADP-ribose) polymerase (PARP) cleavage.

Resistance of D173A mutant to cleavage was associated with increased protection from apoptosis. In fact, D173A Twist-infected cells displayed a reduced penetrance of the apoptotic phenotype in response to different apoptotic stimuli when compared to wild-type Twist-infected cells, as indicated by a decreased fraction of annexin- $V$-reactive cells, a reduced number of apoptotic nuclei (Figure 4d) and an increased cell viability (Figure 4e).

\section{The Twist protein undergoes proteasome- mediated degradation during apoptosis}

To get insights into the biological consequences of caspasemediated proteolysis of Twist, we generated a series of C-terminus-truncated mutants, $\Delta \mathrm{C}$-Twist (Q168 stop), $\Delta \mathrm{C} 1$ Twist (C179 stop) and $\Delta$ C2-Twist (V193 stop). The stop codon introduced in $\Delta \mathrm{C}$-Twist and $\Delta \mathrm{C} 1$-Twist flanks the putative caspase recognition site (codon 170-173). Therefore, these two mutants encode for a protein roughly corresponding to the $\mathrm{N}$-terminus peptide generated following caspase cleavage. E1A/Ras MEF infected with retroviral vectors driving the expression of full-length Twist and Twist truncation mutants were then analyzed by Western blot under normal growth conditions. As shown in Figure 5a, deletion of the C-terminus affected protein stability: despite the presence of high levels of the corresponding mRNA (data not shown), the $\Delta \mathrm{C}$-Twist protein was almost undetectable, while $\Delta \mathrm{C} 1$-Twist and $\Delta \mathrm{C} 2$ Twist showed intermediate levels of expression. Similarly, also the Twist 172-206 mutant, corresponding to the Cterminus $3 \mathrm{kDa}$ peptide generated following caspase cleavage, encoded a highly unstable protein (data not shown). These results suggest that the C-terminus is key for protein stability and that caspase-mediated cleavage of Twist triggers a process that culminates in degradation.

The ubiquitin/proteasome pathway is the major nonlysosomal route for intracellular protein degradation in eucaryotes. Although the relationship between proteasome and apoptosis has been only marginally defined, over the last years evidence has accumulated that modulation in the expression and activity of the various components of the ubiquitin/proteasome system occurs during apoptosis. ${ }^{37-39}$ To verify whether the impaired stability of truncated mutants was at least in part due to proteasome-mediated degradation, cells were incubated with the proteasome inhibitor LLnL ( $N$-acetyl-Leu-Leu-Norleu$\mathrm{Al} ; 50 \mu \mathrm{M}$ for $2 \mathrm{~h}$ ). While the amount of full-length Twist was 

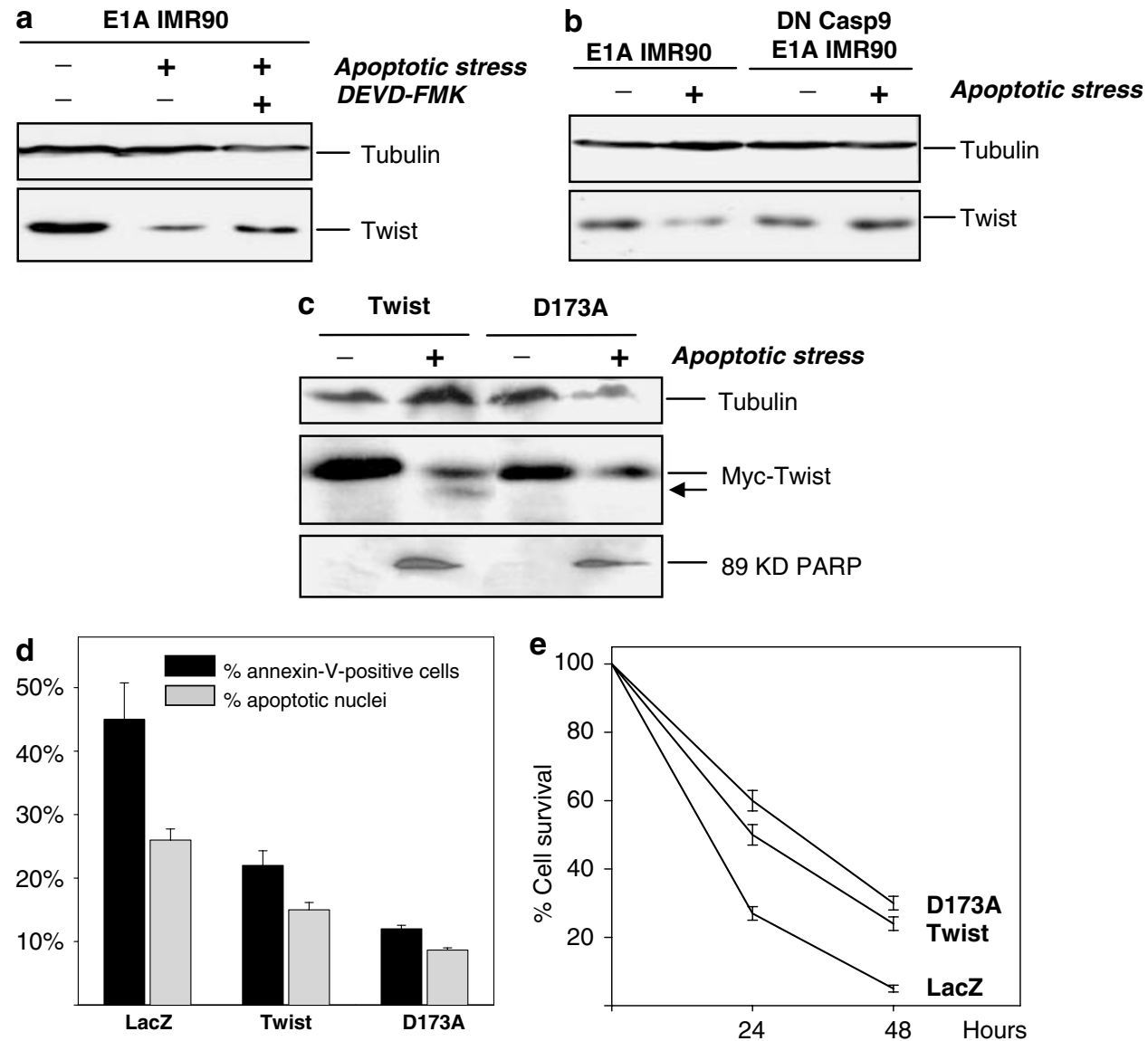

Figure 4 Twist undergoes caspase-mediated proteolysis during apoptosis. (a) Inhibition of the caspase cascade prevents Twist protein downregulation during apoptosis. E1A-transformed IMR 90 cells were subjected to apoptotic stress (cisplatin, $100 \mu \mathrm{M}$ for $24 \mathrm{~h}$ ) in the presence $(+)$ or absence $(-)$ of the caspase inhibitor DEVD-FMK (100 $\mu \mathrm{M}$ for $25 \mathrm{~h}$ ). (b) Inhibition of caspase 9 suppresses apoptosis-related Twist downregulation. Twist protein expression was compared in E1A IMR90 cells and in derivative DN Casp9 E1A IMR90, expressing a dominant-negative mutant of caspase 9. Cells were analyzed for endogenous Twist protein by Western blot before (-) and after (+ ) apoptotic stress (cisplatin, $100 \mu \mathrm{M}$ for $24 \mathrm{~h}$ ) using a human Twist polyclonal serum. Expression of $\alpha$-tubulin was used as a loading control. (c) Twist is target of caspase cleavage in vivo. E1A/Ras MEF engineered to express either Myc-Twist or the D173A Myc-Twist mutant were subjected to apoptotic stress (adriamycin, $0.25 \mu \mathrm{g} / \mathrm{ml}$ for $11 \mathrm{~h}$ ). Cell protein extracts were then resolved on $15 \%$ SDS-PAGE to visualize the cleaved band (indicated by an arrow). Blotting with antiMyc antibody revealed that cleavage was prevented in the D173A mutant. Caspase activation was confirmed by detection of the PARP cleaved band (89 kDa). (d) Abrogation of Twist caspase recognition site enhances Twist protective effect. E1A/Ras MEF ectopically expressing either Twist, the Twist D173A mutant or the irrelevant LacZ control gene were grown on coverslips for $24 \mathrm{~h}$ and then induced to apoptose (adriamycin, $0.1 \mu \mathrm{g} / \mathrm{ml}$ ). At $16 \mathrm{~h}$ after induction, adherent cells were analyzed for annexin- $V$ staining and for nuclei with apoptotic features (peripheral condensation and blebbing into apoptotic bodies). The dark bar indicates the percentage of cells positive for annexin- $V$ reaction. The light bar indicates the percentage of apoptotic nuclei. Similar results were obtained using adriamycin at a concentration of $0.2 \mu \mathrm{g} / \mathrm{ml}$ (not shown). (e) E1A/Ras MEF ectopically expressing Twist, the Twist D173 A mutant or the control LacZ gene were subjected to apoptotic stress (adriamycin, $0.1 \mu \mathrm{g} / \mathrm{ml}$ for 24 and $48 \mathrm{~h}$ ). The number of viable cells at each time point was determined by Trypan blue staining, and normalized for the starting cell number of each culture $(100 \%)$

essentially unaffected by LLnL, the same treatment stabilized the $\Delta \mathrm{C}$-Twist mutant, which was eventually detectable by Western blot (Figure $5 b$ ).

To clarify the role of proteasome in Twist breakdown during apoptosis, cells were subjected to apoptotic stress in the presence of the proteasome inhibitor LLnL. As shown in Figure $5 \mathrm{c}$, a short treatment of the apoptotic cells with LLnL $(50 \mu \mathrm{M}$ for $90 \mathrm{~min})$ allowed the transient stabilization and visualization of the major cleavage fragment $(40 \mathrm{kDa})$, indicating that proteasome-mediated degradation plays an important role in Twist turnover during programmed cell death.

Ubiquitination is the most common mechanism of protein targeting for proteasome-mediated degradation. ${ }^{40-44}$ To test the possibility that the Twist protein was a target of ubiquitination, lysates of E1A IMR90 cells, treated with the proteasome inhibitor LLnL (120 $\mu \mathrm{M}$ for $10 \mathrm{~h})$, were analyzed by Western blot with an anti-human Twist polyclonal serum. The molecular weight of Twist is about $23 \mathrm{kDa}$, while ubiquitin is about $8.5 \mathrm{kDa}$. The appearance of a faint anti-Twist reactive band of about $32 \mathrm{kDa}$ after inhibition of proteasomes supported this hypothesis (Figure 6a). To ascertain whether Twist was actually ubiquitinated, we performed an in vivo ubiquitination assay using hexahistidine-tagged Twist as a substrate. Mouse $\mathrm{His}_{6}$-Twist constructs (carrying a $6 \mathrm{xHis} / \mathrm{Myc}$ tag fused to either the $\mathrm{C}$ - or N-terminus of mouse Twist) were cotransfected in HEK293T cells, together with a vector encoding HA-ubiquitin. ${ }^{45}$ At $24 \mathrm{~h}$ post-transfection, cells were lysed in denaturing conditions to prevent deubiquitination and degradation of protein-ubiquitin conjugates. $\mathrm{His}_{6} / \mathrm{Myc}^{-T}$ wist 

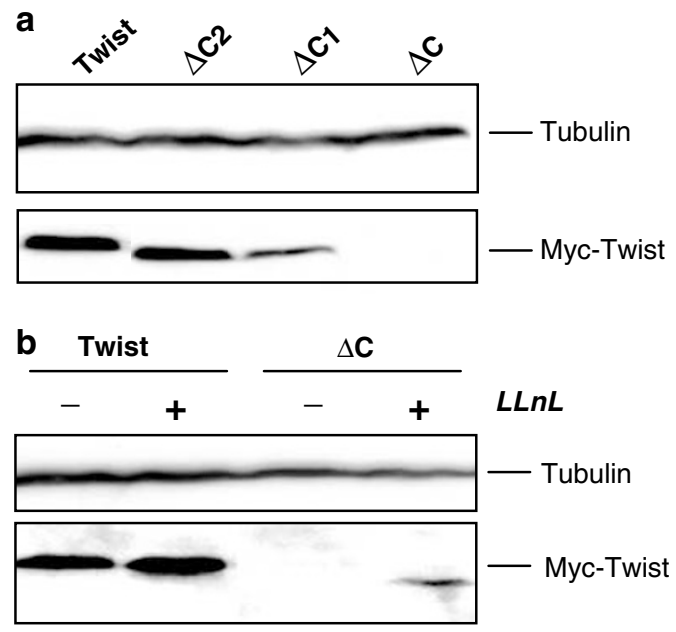

\section{E1A/Ras MEF}

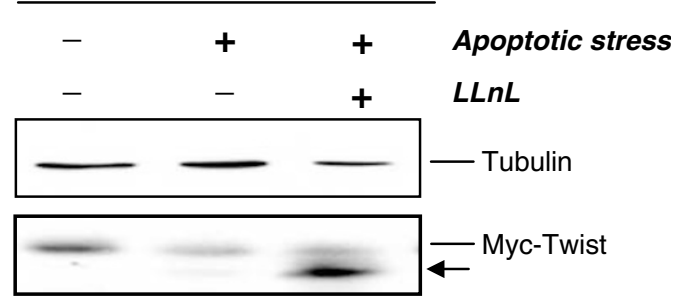

Figure 5 Twist undergoes proteasome-mediated degradation. (a) Twist truncation mutants show different stability when ectopically expressed in E1A/ Ras MEF. Twist, Myc-Twist full length; $\Delta \mathrm{C} 2$, Myc-Twist V193 stop; $\Delta \mathrm{C} 1$, MycTwist C179 stop; $\Delta$ C, Myc-Twist Q168 stop. (b) Inhibition of proteasomemediated degradation rescues the expression of Twist truncated mutants. E1A/ Ras MEF infected with retroviral vectors driving the expression of either MycTwist or Myc-Twist- $\Delta \mathrm{C}$ were incubated in the presence $(+)$ or absence $(-)$ of proteasome inhibitor LLnL (50 $\mu \mathrm{M}$ for $2 \mathrm{~h}$ ). (c) E1A/Ras MEF engineered to express Myc-Twist were subjected to apoptotic stress (adriamycin, $0.25 \mu \mathrm{g} / \mathrm{ml} \mathrm{for}$ $5 \mathrm{~h})$ in the presence $(+)$ or absence $(-)$ of the proteasome inhibitor LLnL $(50 \mu \mathrm{M}$ for $90 \mathrm{~min})$. Cell lysates were then resolved on $15 \%$ SDS-PAGE and probed with anti-Myc antibody. The arrow indicates the Twist major cleavage fragment, which becomes stabilized following inhibition of proteasomes

was purified from cell lysates by Ni-NTA (nickel-nitrilotriacetic acid) chromatography, resolved on SDS-PAGE and probed with anti-HA and anti-Myc. As shown in Figure 6b, cotransfection of HA-ubiquitin together with Twist resulted in the appearance of a ladder, where each band had the apparent molecular mass predicted for $\mathrm{His}_{6} /$ Myc-Twist ubiquitin conjugates. The ladder was detectable with either forms of $\mathrm{His}_{6} /$ Myc-tagged Twist ( $\mathrm{N}$ - and C-terminus), whereas it was undetectable in the absence of HA-ubiquitin. On the whole, these data indicated that Twist is substrate of ubiquitination in vivo. Moreover, the fact that these experiments were conducted in the absence of apoptotic stimuli, together with the observation that also the D173A mutant was susceptible to ubiquitin conjugation (data not shown), supports the notion that ubiquitination may play a more general role in the regulation of Twist turnover, regardless of caspase activation, and that caspase-mediated cleavage may boost this phenomenon.

Two ubiquitin/proteasome pathways are described: an $\mathrm{N}$ terminus-dependent pathway and a lysine-dependent path- way. The pathways are characterized by the site of initial ubiquitination of the protein, the $\mathrm{N}$-terminus or an internal lysine, respectively. ${ }^{46}$ The fact that both $\mathrm{N}$ - and C-terminustagged Twist proteins were susceptible to ubiquitination ruled out the $\mathrm{N}$-terminus pathway. Twist has 10 internal lysine residues, which could be the potential targets for the lysinedependent pathway. To map which of these residues were essential for ubiquitination, we constructed several deletion mutants lacking specific internal lysines (Figure $6 c$ and d). Cotransfection experiments with HA-ubiquitin showed that all mutants, irrespective of the lysine residue deleted, underwent ubiquitination (Figure $6 c$ and d). This indicates that no specific lysine is essential for Twist ubiquitination and that Twist, similar to other transcription factors, ${ }^{45-47}$ has probably multiple internal sites of ubiquitination.

\section{Discussion}

The commitment of a cell to mitosis, differentiation, senescence or death implies the orchestration of multiple signal transduction pathways, and spatio-temporal control of gene expression is one of the most delicate processes in eucaryote development. Twist is a nuclear protein involved in mesoderm determination and recent data indicate that Twist is involved also in apoptosis and tumorigenesis. ${ }^{18-23}$ Little is known about the pathways that govern Twist activation and how Twist expression is regulated. Although a number of evidence support a strict transcriptional control of Twist expression, a comparative expression analysis in both embryo and adult tissues revealed that Twist mRNA and Twist protein expression patterns do not always perfectly match, ${ }^{5}$ pointing to the existence of post-transcriptional mechanisms of Twist regulation.

The observation that Twist protein levels dramatically decreased during programmed cell death prompted us to investigate a possible link between Twist breakdown and apoptotic machinery. In searching for key motifs in the Twist sequence, we were struck by the finding of a putative caspase $3 / 7$ recognition site at the C-terminus of the Twist protein. We provided evidence that the DELD motif at position 170-173 of the Twist protein was recognized as a cleavage site by caspase 3 in vitro and that caspase-mediated cleavage of Twist actually occurs in vivo during apoptosis.

Twist maintains its nuclear localization during apoptosis, as revealed by fluorescence microscopy analyses of GFP-Twist constructs and nuclear and cytoplasmic fractionations of apoptotic cells (data not shown). Kamada et al. ${ }^{34}$ have recently demonstrated that active caspase 3 , but not caspase 7 , translocates from the cytoplasm to the nucleus during apoptosis, providing evidence on how caspase 3 has access to its numerous nuclear targets. Thus, Twist, similar to other transcription factors, is likely to be processed by caspase 3 directly in the nuclear compartment.

Caspase-mediated cleavage may result in either substrate activation, such as in the case of caspases themselves, or in protein inactivation, such as in the case of several negative regulators of apoptosis. ${ }^{48}$ We have shown that caspasemediated proteolysis results in Twist inactivation. In fact, the fragment generated, lacking the last $33 \mathrm{aa}$, is highly unstable 


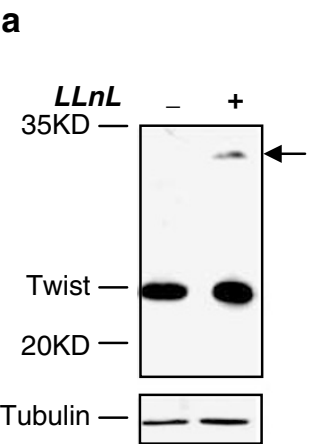

b

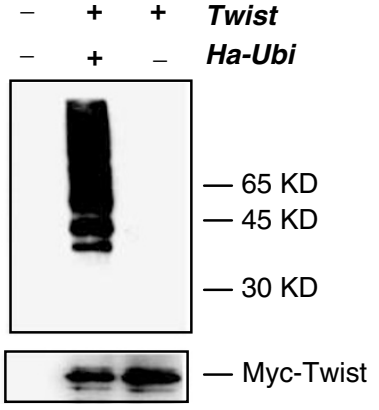

C

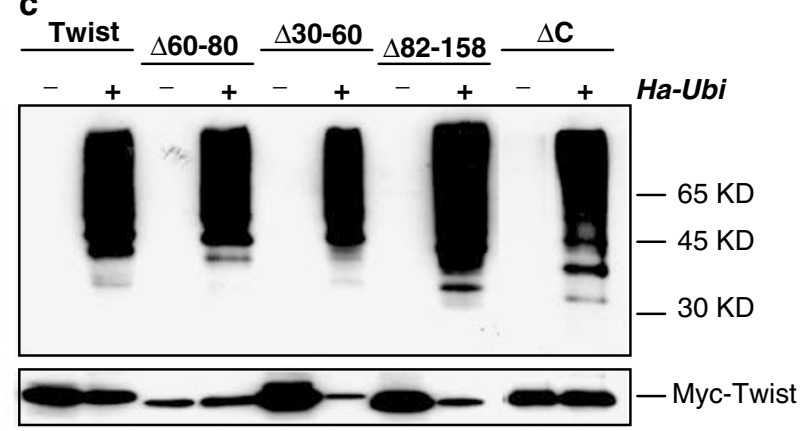

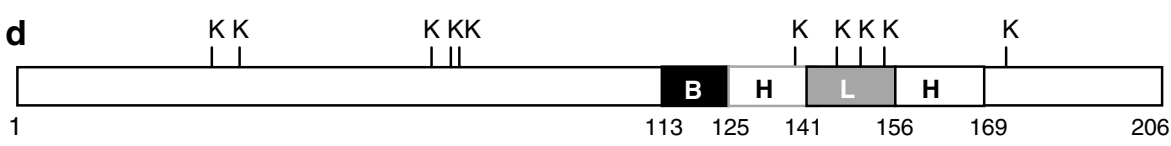

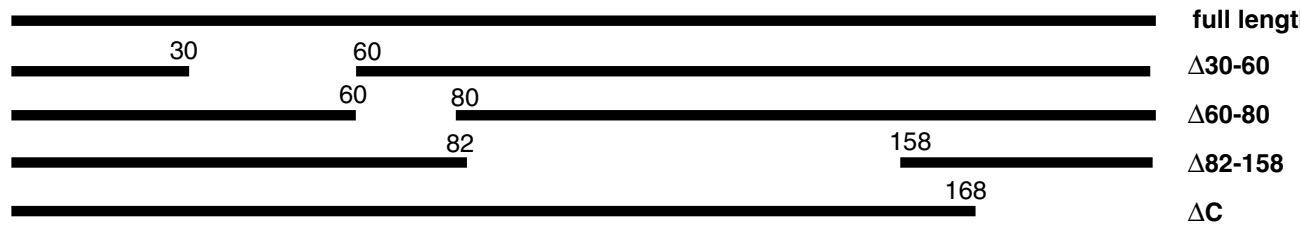

Figure 6 Twist is target of ubiquitination. (a) Cell lysates $(150 \mu \mathrm{g}$ ) of IMR90 cells treated with the proteasome inhibitor LLnL (120 $\mu \mathrm{M}$ for $10 \mathrm{~h}$ ) were resolved on $15 \%$ SDS-PAGE and probed with anti-human polyclonal serum. Long exposure Western blot showed the presence of an additional band (indicated by an arrow) of a molecular mass compatible with monoubiquitinated forms of endogenous Twist. In vivo ubiquitination assays of Myc-Twist full length (b) and Twist deletion mutants (c) were preformed by transiently transfecting HEK293T cells with pCDNA3 HA-ubiquitin and pCDNA3 $\mathrm{His}_{6}$-Myc-Twist constructs as indicated. Data were confirmed by transfecting HA-ubiquitin together with a C-terminus-tagged Twist construct (pCDNA3 Twist-His 6 -Myc, not shown). At $24 \mathrm{~h}$ after transfection, the His ${ }_{6}$-Twist proteins were purified by Ni-NTA chromatography and resolved on SDS-PAGE. Blots were first probed with an anti-HA antibody to detect ubiquitinated forms of Twist (visualized as a ladder in the upper panel) and then reprobed with an anti-Myc antibody to confirm equal loading (lower panel). (d) Structure of the mouse Twist protein and deletion Twist mutants used for in vivo ubiquitination assay: $\Delta 30-60$ (lacking Lys 33 and 38), $\Delta 60-80$ (lacking Lys 73, 76 and 77), $\Delta 82-158$ (lacking Lys 137, 145, 150 and 154) and $\Delta$ C (lacking Lys 176)

and undergoes degradation, in particular proteasomemediated degradation. This was also confirmed by the analysis of a number of truncation mutants, including a mutation detected in Saethre-Chotzen patients. ${ }^{49}$ Abrogation of the putative caspase recognition site resulted in Twist resistance to degradation and enhanced protection toward apoptosis. Taken together, our results indicate that the proteolytic cleavage of Twist in the course of apoptosis functions as a destabilizing process that culminates in protein degradation, and suggest that caspase-mediated cleavage plays a role in spatio-temporal control of the antiapoptotic activity of Twist.

Twist breakdown in the course of apoptosis could be prevented in part by treatment with proteasome inhibitors, indicating that Twist undergoes proteasome-mediated degradation. We then provided evidence that Twist is actually a target of ubiquitination in vivo and that ubiquitination of Twist occurs as a widespread phenomenon, since no single lysine is essential for its ubiquitin conjugation. Our data support the notion that, similar to other short-lived transcription factors, Twist levels are likely maintained at appropriate spatiotemporal levels by targeted ubiquitination and degradation via the proteasome pathway, ${ }^{44,46,50-52}$ and that during apoptosis this phenomenon may be boosted as a result of caspase cleavage.

Numerous reports support a link between the ubiquitin/ proteasome pathway and apoptosis. Many molecules in- volved in cell cycle control and apoptosis, such as p53, IAPs and certain bcl-2 family members, ${ }^{50,53,54}$ undergo ubiquitinmediated degradation. Moreover, a number of mediators of survival pathways have been shown to be turned off as a consequence of caspase-dependent cleavage. ${ }^{48}$ Here we report a situation where caspase-mediated cleavage generates an unstable protein that rapidly undergoes proteasomemediated degradation, providing a direct link between the two proteolytic systems during apoptosis.

Besides apoptosis, it is likely that caspase-mediated cleavage may play an important role in the regulation of Twist expression also during tissue determination and embryo morphogenesis. An increasing body of evidence points to nonapoptotic functions of caspases in the control of cellular proliferation and differentiation, and it has been suggested that in some instances cell determination might be seen as a kind of 'incomplete apoptosis'. ${ }^{55}$ In fact, differentiation of erythrocytes, megakaryocytes and macrophages all involve caspase activation and proteolytic cleavage of specific substrates. ${ }^{56-59}$ Caspase activation is required also for the differentiation of muscle and bone and, consistently, caspase 3-deficient mice show a dramatic reduction in muscle mass. ${ }^{60,61}$ Twist has been shown to inhibit both myogenic and osteogenic differentiation and, in fact, in mouse embryo the activation of these differentiation programs is associated with Twist turn off. The intriguing parallel between Twist downregulation and caspase activation in differentiating 
mesodermal structures suggests a role for a caspasemediated tuning of Twist in terminal differentiation. This is reminiscent of what was recently reported about another member of the bHLH family of transcription factors, SCL/Tal1 , which regulates hematopoietic cell survival and differentiation through a caspase-mediated process. ${ }^{62,63}$

Finally, the Twist protein has been reported to be accumulated in sarcomas, lymphomas and certain types of carcinomas, ${ }^{18-20}$ while unstable forms of Twist have often been detected in Saethre-Chotzen patients. ${ }^{49}$ In both instances, the biochemical bases for the altered expression of Twist are presently unknown. Our data outline the possibility that defects in post-transcriptional regulation of Twist may play a role in human tumorigenesis and developmental diseases.

In summary, we have provided evidence of post-transcriptional regulation of Twist. We have shown that Twist undergoes proteasome degradation and that this phenomenon is boosted during apoptosis as a result of caspase-mediated cleavage, providing an intriguing link between the two proteolytic pathways. Finally, our findings raise the possibility that Twist processing by caspases may be involved also in tissue determination and that alterations of Twist turnover may account for aberrant expression of Twist observed in human tumors.

\section{Materials and Methods}

\section{Cells and reagents}

E1A/Ras MEF,${ }^{27}$ E1A IMR90, ${ }^{64}$ DN Casp9/E1A IMR90, ${ }^{64}$ U2OS, MCF-7, HEK293T and LinX $A^{18}$ cells were maintained in $5 \% \mathrm{CO}_{2}$ in Dulbecco's modified Eagle's medium (DMEM) supplemented with $10 \%$ of fetal bovine serum (GIBCO-BRL). Balb/C 3T3 cells were grown in DMEM (GIBCO$B R L$ ) supplemented with $10 \%$ calf serum (GIBCO-BRL). E1A/Ras $B J^{65}$ were grown in advanced MEM (GIBCO-BRL) plus $2 \%$ fetal bovine serum (GIBCO-BRL).

A standard calcium phosphate precipitation protocol was used for transfection of HEK293T and the packaging cell line LinX A, while MCF-7 cells were transfected using the FuGene 6 transfection reagent (Roche Molecular Biochemicals). Retroviral infections were performed as described previously. ${ }^{18}$

LLnL (Sigma) was dissolved in DMSO and used at concentrations and times indicated. Caspase 3 inhibitors Z-DEVD-FMK (Calbiochem Merck), Z-VAD (Z-Val-Ala-Asp(OCH3)-FMK) (Calbiochem Merck) and Ac-DEVD$\mathrm{CHO}$ (Ac-Asp-Glu-Val-Asp-CHO) (Bachem Bioscience) were employed at different concentrations as described.

\section{Plasmids}

All Twist constructs used in this study are either Myc or FLAG tagged. Fulllength pCS2 mouse Myc-Twist, containing a 6xMyc epitope at the Nterminus of the protein, was a kind gift from Andrew Lassar. FLAG-Twist was generated by cloning the rat Twist CDNA ${ }^{18}$ in the PCMV FLAG vector (Stratagene). His 6 -Myc-Twist contains both a $6 \mathrm{xH}$ is and a $6 \mathrm{xMyc}$ tag at the $\mathrm{N}$-terminus of Twist CDNA and was obtained by subcloning the mouse Myc-Twist cDNA into a pCDNA3 expression plasmid containing a $\mathrm{His}_{6} \mathrm{~N}$ terminal tag. Twist-Myc-His ${ }_{6}$ contains both a $6 x \mathrm{His}$ and a Myc tag at the $\mathrm{C}$ terminus of Twist cDNA and was generated by subcloning the mouse Twist cDNA into the pCDNA3.1 Myc/His ${ }_{6}$ plasmid (Invitrogen). pCMV HA-
Ubi, encoding for an HA-tagged ubiquitin, was a kind gift from Dirk Bohmann. pEGFP-caspase 3 was generated by subcloning caspase 3 cDNA into the pEGFP $\mathrm{C} 1$ vector (Clontech). All Twist mutants described in this study were generated by site-directed mutagenesis (QuikChange ${ }^{\mathrm{TM}}$ Site Directed Mutagenesis Kit, Stratagene) and checked by sequencing. For retroviral infections, Myc-Twist full-length and derived mutants were subcloned into pBABE Puro retroviral vector. ${ }^{18}$ pBABE Puro LacZ, encoding an irrelevant gene (LaCZ), was used as a control.

\section{Immunoblots}

Cells were collected and lysed in RIPA buffer (0.5\% Na desoxycholate, $0.5 \%$ NP- $-40,0.05 \%$ SDS in phosphate-buffered saline (PBS)) supplemented with protease inhibitor cocktail (Complete, Roche Molecular Biochemicals). Protein content was determined using the Bradford assay. The cell lysates ( $50 \mu \mathrm{g}$, unless differently specified) were subjected to SDS-PAGE, transferred onto Protran nitrocellulose membrane (Schleicher \& Shuell) and probed with different antibodies. The antibodies used included anti-Myc (Oncogene Science) to detect the expression of MycTwist constructs, anti-HA (Roche Molecular Biochemicals) to detect the HA-ubiquitin conjugates, anti-PARP antibody (Chemicon International) to monitor PARP cleavage and anti- $\alpha$-tubulin (Oncogene Science) for protein normalization. Human Twist was detected with rabbit polyclonal, affinitypurified antibodies raised against a synthetic keyhole limpet hemocyanin (KLH)-conjugated peptide homologous to the N-terminus of human Twist (aa 24-35, PDRQQPPSGKRGC). Blots were developed with the enhanced chemiluminescence immunodetection system (Amersham).

\section{Northern blot and semiquantitative RT-PCR analysis}

Total RNA was extracted using the Trizol reagent (GIBCO-BRL) according to the manufacturer's instructions. Northern blot analysis was performed as described. ${ }^{18}$ Blots were hybridized with a ${ }^{32} \mathrm{P}$-dCTP-labeled mouse Twist-specific probe. A $\beta$-actin probe was used to confirm equal loading.

For human Twist RNA expression analysis, a semiquantitative RT-PCR was performed on cDNAs synthesized from $1 \mu \mathrm{g}$ of total RNA using random hexamers (Pharmacia Biosciences) and AMV reverse transcriptase (Promega) in a $20 \mu$ reaction, as described previously. ${ }^{66}$ PCR was performed in a final volume of $50 \mu \mathrm{l}$ in the presence of 1/20th of CDNA reaction, $25 \mathrm{pmol}$ of each primer, $200 \mu \mathrm{mol} / / \mathrm{dNTPs}, 1.5 \mathrm{mmol} / / \mathrm{MgCl}_{2}$ and $2 \mathrm{U}$ of Taq DNA polymerase (Promega). The following primers were used: Twist 5 sense, $5^{\prime}$-GCAAACAGTCGCTGAACGAC-3'; Twist 7 anti, $5^{\prime}$ CCATTTTCTCCTTCTCTGGAA-3'; $\beta$-actin 680 sense, $5^{\prime}$-CACGGCC GAGCGGGAAATCGT-3'; $\beta$ actin $3^{\prime}$ anti, 5'-GCGGTGGACGATG GAGGGGC-3'. For Twist mRNA quantitation, 25, 35 and 45 cycles of PCR reactions were compared to a 25 -cycle $\beta$-actin PCR. PCR conditions were as follows: one step of $95^{\circ} \mathrm{C}$ for $5 \mathrm{~min}$, followed by cycles of $30 \mathrm{~s}$ at $94^{\circ} \mathrm{C}, 30 \mathrm{~s}$ at $55^{\circ} \mathrm{C}, 30 \mathrm{~s}$ at $70^{\circ} \mathrm{C}$ as specified. PCR were resolved onto $2.5 \%$ agarose gels.

\section{In vitro caspase cleavage assay}

In vitro caspase cleavage assay was performed according to Chen et al. ${ }^{67}$ with minor modifications. Briefly, full length and D173A Twist mutant, cloned into pCS2 vector, were in vitro translated with $\left[{ }^{35}\right.$ S]methionine using the TNT transcription/translation system (Promega). A $5 \mu$ l portion of in vitro-translated Twist was incubated for different durations (from 1 to $16 \mathrm{~h}$ ) at $37^{\circ} \mathrm{C}$ with $80 \mu \mathrm{g}$ of apoptotic cell lysates in a buffer containing 
$10 \mathrm{mM}$ Hepes/KOH pH 7.9, CHAPS $0.01 \%$ and $1 \mathrm{mM} \mathrm{DTT}$, in the presence or absence of $1 \mu \mathrm{M}$ Z-DEVD-FMK. The reaction mixture was then loaded onto a $15 \%$ SDS-polyacrylamide gel. Apoptotic cell lysates were obtained by treating $\mathrm{E} 1 \mathrm{~A} / \mathrm{Ras} \mathrm{MEF}$ with $0.5 \mu \mathrm{g} / \mathrm{ml}$ of adriamycin for $16 \mathrm{~h}$, or by treating MCF-7 and derivative MCF-7/caspase 3 cells with $2 \mu \mathrm{g} /$ $\mathrm{ml}$ adriamycin for $24 \mathrm{~h}$. Cells were lysed in a buffer containing $10 \mathrm{mM}$ Hepes/KOH pH 7.9, 0.1\% CHAPS, $2 \mathrm{mM}$ EDTA, $5 \mathrm{mM}$ DTT and $1 \mathrm{mM}$ PMSF. For in vitro caspase cleavage assay, either $1 \mu \mathrm{l}$ of in vitrotranslated Myc-Twist or in vitro-translated caspase 2 was incubated with $0.1 \mathrm{ng}$ of recombinant caspase 3 in a buffer containing $50 \mathrm{mM}$ PIPES pH 6.5, $1 \mathrm{mM}$ EDTA, $1 \mathrm{mM}$ PMSF and $1 \mathrm{mM}$ DTT for $1 \mathrm{~h}$ at $37^{\circ} \mathrm{C}$. Ac-DEVD$\mathrm{CHO}$ was added where indicated at a concentration of $2 \mu \mathrm{M}$. The reaction was terminated by adding one volume of $2 \times$ Laemmli buffer and boiling for $3 \mathrm{~min}$. Gels were then dried and exposed to X-ray films (Kodak). ${ }^{64}$

\section{In vivo caspase cleavage assay}

E1A/Ras MEF were engineered to express Myc-Twist (either full length or D173A mutant) following retroviral infection with a pBABE Puro Myc-Twist construct. A pBABE Puro LacZ vector, driving the expression of the LacZ irrelevant gene, was used as a control. Cells were induced to apoptose by treatment with adriamycin $(0.25 \mu \mathrm{g} / \mathrm{ml})$. After $11 \mathrm{~h}$, cells were collected by scraping in ice-cold PBS and split in two aliquots. For Twist analysis, cell pellets were directly lysed in Laemmli buffer. For the detection of PARP cleavage, pellets were lysed in a buffer containing $50 \mathrm{mM}$ Tris- $\mathrm{HCl} \mathrm{pH} 6.8$, $6 \mathrm{M}$ urea, $6 \%$ 2-mercaptoethanol, 3\% SDS and 0.003\% bromophenol blue, followed by sonication. Cell lysates $(100 \mu \mathrm{g})$ were resolved by SDSPAGE (15\% for Twist and $7.5 \%$ for PARP).

\section{Apoptosis in E1A/Ras MEF cells}

Protection from apoptosis by Twist and by the D173A mutant in E1A/Ras MEF was evaluated using three independent assays. Annexin- $V$ binding to phosphatidylserine allowed the recognition of early phases of apoptosis and was performed using the annexin-V-FLUOS staining kit (Roche Molecular Biochemicals) according to the manufacturer's instruction. Hoechst 33342 staining of apoptotic nuclei and the Trypan blue exclusion test to assess cell viability were performed as described previously. ${ }^{18}$ Briefly, for annexin-V labeling and Hoechst 33342 staining, E1A/Ras MEF, engineered to express Myc-tagged wild-type Twist, the D173 A mutant or the control gene LacZ, were plated at low density on acid-treated coverslips. At $24 \mathrm{~h}$ after plating, apoptosis was triggered by treatment with either 0.1 or $0.2 \mu \mathrm{g} / \mathrm{ml}$ adriamycin. At $16 \mathrm{~h}$ after induction, slides were stained with the annexin-V-FLUOS labeling solution in the presence of $4 \mu \mathrm{g} / \mathrm{ml}$ of the Hoechst 33342 nuclear dye for $15 \mathrm{~min}$ and then mounted. At least 50 fields/slide were analyzed. Data are reported as percentage of adherent cells reactive for annexin- $V$ and percentage of nuclei showing peripheral condensation and blebbing into apoptotic bodies. For Trypan blue exclusion test, cells were seeded into $6 \mathrm{~cm}$ plates $\left(3 \times 10^{5}\right.$ cells/plate) $24 \mathrm{~h}$ prior to induction of apoptosis. At 24 and $48 \mathrm{~h}$ after treatment with adriamycin $(0.1 \mu \mathrm{g} / \mathrm{ml})$, adherent and nonadherent cells were pooled, stained with Trypan blue and counted under a microscope. Survival was expressed as number of viable cells $\times 100 /$ number of cells plated.

\section{In vivo ubiquitination assay}

A total of $20 \mu \mathrm{g}$ DNA per $10 \mathrm{~cm}$ dish $\left(4 \mu \mathrm{g}\right.$ of pCDNA3 $\mathrm{His}_{6}$-Myc-Twist or pCDNA3.1 Twist-Myc-His ${ }_{6}$ constructs plus $3 \mu \mathrm{g}$ pCMV HA-Ubi and $13 \mu \mathrm{g}$ carrier DNA) was transfected in HEK293T cells by the calcium phosphate method. At $24 \mathrm{~h}$ after transfection, cells were collected and $\mathrm{His}_{6}$ protein purification was performed as described. ${ }^{68}$ Briefly, cells were lysed in $2 \mathrm{ml}$ of $6 \mathrm{M}$ guanidium- $\mathrm{HCl}, 0.1 \mathrm{M} \mathrm{Na} 2 \mathrm{HPO}_{4} / \mathrm{NaH}_{2} \mathrm{PO}_{4}(\mathrm{pH} 8.0$ ) plus $5 \mathrm{mM}$ imidazole. Lysates were mixed with $0.2 \mathrm{ml}$ of $50 \%$ slurry Ni-NTA agarose (Qiagen) and incubated for $4 \mathrm{~h}$ at room temperature on a rotator. The slurries were applied to a Bio-Rad Econo-column and washed as described. Proteins were eluted in a protein elution buffer $(50 \mathrm{mM}$ $\mathrm{Na}_{2} \mathrm{HPO}_{4} / \mathrm{NaH}_{2} \mathrm{PO}_{4}$ (pH 8.0), $100 \mathrm{mM} \mathrm{KCl}, 0.2 \% \mathrm{NP}-40,20 \%$ glycerol) supplemented with $200 \mathrm{mM}$ imidazole. Eluates were then TCA precipitated and resolved on SDS-PAGE. Immunoblotting was performed with anti-HA and anti-Myc antibodies.

\section{Acknowledgements}

We thank D Bohmann, S Lowe, A Lassar, GJ Hannon, C Kuhne, $Y$ Lazebnik and $D$ Turner for kindly providing reagents and $L$ Banks, MG Cangi, M Boiocchi and $\mathrm{H}$ Keehu for critical reading of the manuscript. This work was supported by the Italian Association for Cancer Research (AIRC).

\section{References}

1. Thisse B, el Messal M and Perrin-Schmitt F (1987) The twist gene: isolation of a Drosophila zygotic gene necessary for the establishment of dorsoventral pattern. Nucleic Acids Res. 15: 3439-3453

2. Fuchtbauer EM (1995) Expression of M-Twist during postimplantation development of the mouse. Dev. Dyn. 204: 316-322

3. Bate M, Rushton E and Currie DA (1991) Cells with persistent twist expression are the embryonic precursors of adult muscles in Drosophila. Development 113: $79-89$

4. Hebrok M, Wertz K and Fuchtbauer EM (1994) M-twist is an inhibitor of muscle differentiation. Dev. Biol. 165: 537-544

5. Gitelman I (1997) Twist protein in mouse embryogenesis. Dev. Biol. 189: 205214

6. Murray SS, Glackin CA, Winters KA, Gazit D, Kahn AJ and Murray EJ (1992) Expression of helix-loop-helix regulatory genes during differentiation of mouse osteoblastic cells. Bone Miner. Res. 7: 1131-1138

7. Lee MS, Lowe GN, Strong DD, Wergedal JE and Glackin CA (1999) TWIST, a basic helix-loop-helix transcription factor, can regulate the human osteogenic lineage. J. Cell. Biochem. 75: 566-577

8. Spicer DB, Rhee J, Cheung WL and Lassar AB (1996) Inhibition of myogenic bHLH and MEF2 transcription factors by the bHLH protein Twist. Science 272: 1476-1480

9. Hamamori Y, Wu HY, Sartorelli V and Kedes L (1997) The basic domain of myogenic basic helix-loop-helix (bHLH) proteins is the novel target for direct inhibition by another bHLH protein, Twist. Mol. Cell. Biol. 17: 6563-6573

10. Leshem Y, Spicer DB, Gal-Levi R and Halevy O (2000) Hepatocyte growth factor (HGF) inhibits skeletal muscle cell differentiation: a role for the bHLH protein twist and the cdk inhibitor p27. J. Cell. Physiol. 184: 101-119

11. Zhao P and Hoffman EP (2004) Embryonic myogenesis pathways in muscle regeneration. Dev. Dyn. 229: 380-392

12. El Ghouzzi V, Le Merrer M, Perrin-Schmitt F, Lajeunie E, Benit P, Renier D, Bourgeois P, Bolcato-Bellemin AL, Munnich A and Bonaventure J (1997) Mutations of the TWIST gene in the Saethre-Chotzen syndrome. Nat. Genet. 15: $42-46$

13. Howard TD, Paznekas WA, Green ED, Chiang LC, Ma N, Ortiz De Luna RI, Garcia Delgado C, Gonzales-Ramos M, Kline AD and Jabs EW (1997) Mutations in TWIST, a basic helix-loop-helix transcription factor, in SaethreChotzen syndrome. Nat. Genet. 15: 36-41

14. El Ghouzzi V, Lajeunie E, Le Merrer M, Cormier-Daire V, Renier D, Munnich A and Bonaventure J (1999) Mutations within or upstream of the basic helixloop-helix domain of the TWIST gene are specific to Saethre-Chotzen syndrome. Eur. J. Hum. Genet. 7: 27-33 
15. Gripp K, Zackai E and Stolle C (2000) Mutations in the human TWIST gene. Hum. Mutat. 15: 150-155

16. El Ghouzzi V, Legeai-Mallet L, Aresta S, Benoist C, Munnich A, de Gunzburg J and Bonaventure J (2000) Saethre-Chotzen mutations cause TWIST protein degradation or impaired nuclear location. Hum. Mol. Genet. 9: 813-819

17. Chen ZF and Behringer RR (1995) Twist is required in head mesenchyme for cranial neural tube morphogenesis. Genes Dev. 9: 686-699

18. Maestro R, Dei Tos AP, Hamamori Y, Krasnokutski S, Sartorelli V, Kedes L, Doglioni C, Beach DH and Hannon GJ (1999) Twist is a potential oncogene that inhibits apoptosis. Genes Dev. 13: 2207-2217

19. Yang J, Mani SA, Donaher JL, Ramaswamy S, Itzykson RA, Come C, Savagner P, Gitelman I, Richardson A and Weinberg RA (2004) Twist, a master regulator of morphogenesis, plays an essential role in tumor metastasis. Cell 117: 927-939

20. van Doorn R, Dijkman R, Vermeer MH, Out-Luiting JJ, van der Raaij-Helmer EM, Willemze R and Tensen CP (2004) Aberrant expression of the tyrosine kinase receptor EphA4 and the transcription factor twist in Sezary syndrome identified by gene expression analysis. Cancer Res. 64: 5578-5586

21. Wang $X$, Ling MT, Guan XY, Tsao SW, Cheung HW, Lee DT and Wong YC (2004) Identification of a novel function of TWIST, a bHLH protein, in the development of acquired taxol resistance in human cancer cells. Oncogene 23: 474-482

22. Dupont J, Fernandez AM, Glackin CA, Helman L and LeRoith D (2001) Insulinlike growth factor 1 (IGF-1)-induced twist expression is involved in the antiapoptotic effects of the IGF-1 receptor. J. Biol. Chem. 276: 26699-26707

23. Sosic D, Richardson JA, Yu K, Ornitz DM and Olson EN (2003) Twist regulates cytokine gene expression through a negative feedback loop that represses NFkappaB activity. Cell 112: 169-180

24. Yousfi M, Lasmoles F, El Ghouzzi V and Marie PJ (2002) Twist haploinsufficiency in Saethre-Chotzen syndrome induces calvarial osteoblast apoptosis due to increased TNFalpha expression and caspase-2 activation. Hum. Mol. Genet. 11: 359-369

25. Zuniga A, Quillet R, Perrin-Schmitt $F$ and Zeller R (2002) Mouse Twist is required for fibroblast growth factor-mediated epithelial-mesenchymal signalling and cell survival during limb morphogenesis. Mech. Dev. 114: 51-59

26. O'Rourke MP and Tam PP (2002) Twist functions in mouse development. Int. J. Dev. Biol. 46: 401-413

27. Lowe SW and Ruley HE (1993) Stabilization of the p53 tumor suppressor is induced by adenovirus $5 \mathrm{E} 1 \mathrm{~A}$ and accompanies apoptosis. Genes Dev. 7: $535-545$

28. Shi $Y$ (2002) Mechanisms of caspase activation and inhibition during apoptosis. Mol. Cell 9: 459-470

29. Cryns V and Yuan J (1999) Proteases to die for. Genes Dev. 13: 1551-1570

30. Thornberry NA and Lazebnik Y (1998) Caspases: enemies within. Science 281: 1312-1316

31. Thornberry NA, Rano TA, Peterson EP, Rasper DM, Timkey T, Garcia-Calvo M, Houtzager VM, Nordstrom PA, Roy S, Vaillancourt JP, Chapman KT and Nicholson DW (1997) A combinatorial approach defines specificities of members of the caspase family and granzyme B. Functional relationships established for key mediators of apoptosis. J. Biol. Chem. 272: 17907-17911

32. Adrain C and Martin SJ (2001) The mitochondrial apoptosome: a killer unleashed by the cytochrome seas. Trends Biochem. Sci. 26: 390-397

33. Wang $X$ (2001) The expanding role of mitochondria in apoptosis. Genes Dev. 15: 2922-2933

34. Kamada S, Kikkawa U, Tsujimoto $Y$ and Hunter T (2005) Nuclear translocation of caspase-3 is dependent on its proteolytic activation and recognition of a substrate-like protein(s). J. Biol. Chem. 280: 857-860

35. Janicke RU, Sprengart ML, Wati MR and Porter AG (1998) Caspase-3 is required for DNA fragmentation and morphological changes associated with apoptosis. J. Biol. Chem. 273: 9357-9360

36. Fearnhead HO, Rodriguez J, Govek EE, Guo W, Kobayashi R, Hannon G and Lazebnik YA (1998) Oncogene-dependent apoptosis is mediated by caspase-9. Proc. Natl. Acad. Sci. USA 95: 1366413669

37. Wojcik C (1999) Proteasomes in apoptosis: villains or guardians? Cell Mol. Life Sci. 56: $908-917$

38. Sun XM, Butterworth M, MacFarlane M, Dubiel W, Ciechanover A and Cohen GM (2004) Caspase activation inhibits proteasome function during apoptosis. Mol. Cell 14: 81-93
39. Lee JC and Peter ME (2003) Regulation of apoptosis by ubiquitination. Immunol. Rev. 193: 39-47

40. Ciechanover A (1994) The ubiquitin-proteasome proteolytic pathway. Cell 79: 13-21

41. Finley D and Chau V (1991) Ubiquitination. Annu. Rev. Cell Biol. 7: 25-69

42. Hershko $A$ and Ciechanover $A$ (1992) The ubiquitin system for protein degradation. Annu. Rev. Biochem. 61: 761-807

43. Hochstrasser M (1992) Ubiquitin and intracellular protein degradation. Curr. Opin. Cell Biol. 4: 1024-1031

44. Jentsch S (1992) Ubiquitin-dependent protein degradation: a cellular perspective. Trends Cell Biol. 2: 98-103

45. Treier M, Staszewski LM and Bohmann D (1994) Ubiquitin-dependent c-Jun degradation in vivo is mediated by the delta domain. Cell 78: 787-798

46. Breitschopf K, Bengal E, Ziv T, Admon A and Ciechanover A (1998) A novel site for ubiquitination: the N-terminal residue, and not internal lysines of $M y 0 D$, is essential for conjugation and degradation of the protein. EMBO J. 17: 5964 5973

47. Salghetti SE, Muratani M, Wijnen H, Futcher B and Tansey WP (2000) Functional overlap of sequences that activate transcription and signal ubiquitinmediated proteolysis. Proc. Natl. Acad. Sci. USA 97: 3118-3123

48. Fisher U, Janicke RU and Schulze-Osthoff $K$ (2003) Many cuts to ruin: a comprehensive update of caspase substrates. Cell Death Differ. 10: 76-100

49. Gripp KW, Stolle CA, Celle L, McDonald-McGinn DM, Whitaker LA and Zackai EH (1999) TWIST gene mutation in a patient with radial aplasia and craniosynostosis: further evidence for heterogeneity of Baller-Gerold syndrome. Am. J. Med. Genet. 82: 170-176

50. Maki CG, Huibregtse JM and Howley PM (1996) In vivo ubiquitination and proteasome-mediated degradation of p53. Cancer Res. 56: 26492654

51. Chen Z, Hagler J, Palombella VJ, Melandri F, Scherer D, Ballard D and Maniatis T (1995) Signal-induced site-specific phosphorylation targets I kappa B alpha to the ubiquitin-proteasome pathway. Genes Dev. 9: 1586-1597

52. Gregory MA and Hann SR (2000) C-Myc proteolysis by the ubiquitinproteasome pathway: stabilization of c-Myc in Burkitt's lymphoma cells. Mol. Cell. Biol. 20: 2423-2435

53. Yang Y, Fang S, Jensen JP, Weissman AM and Ashwell JD (2000) Ubiquitin protein ligase activity of IAPs and their degradation in proteasomes in response to apoptotic stimuli. Science 288: 874-877

54. Zhang HG, Wang J, Yang X, Hsu HC and Mountz JD (2004) Regulation of apoptosis proteins in cancer cells by ubiquitin. Oncogene 23: 20092015

55. Schwerk C and Schulze-Osthoff K (2003) Non-apoptotic functions of caspases in cellular proliferation and differentiation. Biochem. Pharmacol. 66: 1453-1458

56. De Maria R, Zeuner A, Eramo A, Domenichelli C, Bonci D, Grignani $F$, Srinivasula SM, Alnemri ES, Testa U and Peschle C (1999) Negative regulation of erythropoiesis by caspase-mediated cleavage of GATA-1. Nature 401: 489-493

57. Zermati $Y$, Garrido C, Amsellem S, Fishelson S, Bouscary D, Valensi F, Varet $B$, Solary $E$ and Hermine $O$ (2001) Caspase activation is required for terminal erythroid differentiation. Exp. Med. 193: 247-254

58. De Botton S, Sabri S, Daugas E, Zermati Y, Guidotti JE, Hermine O, Kroemer $G$, Vainchenker W and Debili N (2002) Platelet formation is the consequence of caspase activation within megakaryocytes. Blood 100: 1310-1317

59. Sordet O, Rebe C, Plenchette S, Zermati Y, Hermine O, Vainchenker W, Garrido C, Solary E and Dubrez-Daloz L (2002) Specific involvement of caspases in the differentiation of monocytes into macrophages. Blood 100: 4446-4453

60. Fernando P, Kelly JF, Balazsi K, Slack RS and Megeney LA (2002) Caspase 3 activity is required for skeletal muscle differentiation. Proc. Natl. Acad. Sci. USA 99: $11025-11030$

61. Mogi M and Togari A (2003) Activation of caspases is required for osteoblastic differentiation. J. Biol. Chem. 278: 47477-47482

62. Condorelli GL, Tocci A, Botta R, Facchiano F, Testa U, Vitelli L, Valtieri M, Croce CM and Peschle C (1997) Ectopic TAL-1/SCL expression in phenotypically normal or leukemic myeloid precursors: proliferative and antiapoptotic effects coupled with a differentiation blockade. Mol. Cell. Biol. 17: 2954-2969

63. Zeuner A, Eramo A, Testa U, Felli N, Pelosi E, Mariani G, Srinivasula SM, Alnemri ES, Condorelli G, Peschle C and De Maria R (2003) Control of 
erythroid cell production via caspase-mediated cleavage of transcription factor SCL/Tal-1. Cell Death Differ. 10: 905-913

64. Paroni G, Mizzau M, Henderson C, Del Sal G, Schneider C and Brancolini C (2004) Caspase-dependent regulation of histone deacetylase 4 nuclear-cytoplasmic shuttling promotes apoptosis. Mol. Biol. Cell 15: 28042818

65. Seger YR, Garcia-Cao M, Piccinin S, Cunsolo CL, Doglioni C, Blasco MA Hannon GJ and Maestro R (2002) Transformation of normal human cells in the absence of telomerase activation. Cancer Cell 2: 401-413
66. Gasparotto D, Maestro R, Piccinin S, Vukosavljevic T, Barzan L, Sulfaro S and Boiocchi M (1997) Overexpression of CDC25A and CDC25B in head and neck cancers. Cancer Res. 57: 2366-2368

67. Chen L, Marechal V, Moreau J, Levine AJ and Chen J (1997) Proteolytic cleavage of the mdm2 oncoprotein during apoptosis. J. Biol. Chem. 272: 22966-22973

68. Kuhne C and Banks L (1998) E3-ubiquitin ligase/E6-AP links multicopy maintenance protein 7 to the ubiquitination pathway by a novel motif, the L2G box. J. Biol. Chem. 273: 34302-34309 